\title{
An Examination of the Relationship between Perceived price Fairness on Customer Satisfaction and Loyalty in Kenyan Star-Rated Restaurants.
}

\author{
Margaret Githiri \\ Egerton University, Faculty of Environmental and Resource Development, \\ P. O, Box 536- 20115, Egerton, Kenya
}

\begin{abstract}
:
Perceived price fairness is an important predictor of relationship quality, trust, satisfaction and loyalty of customers visiting restaurants. Although several studies on customer satisfaction and loyalty have been done, little is still known about customer satisfaction and loyalty regarding perceived price fairness in Kenyan rated restaurants. The main objective of the study was therefore to examine the relationship between perceived price fairness on customers' satisfaction and loyalty at rated restaurants in Nairobi and Coastal region. A cross sectional survey study was used in recording the information that is present in the population. Simple random sampling method was used in selecting 345 customers used in the study. The target population included all customers visiting the selected restaurants. Structured questionnaires were used in acquiring relevant information from customers. Descriptive statistics and inferential statistics (linear regression analysis) were used in analyzing the objective. The results indicated significant relationship between perceived price with satisfaction and return intention $(p<0.05)$, leading to the rejection of the hypotheses. Majority of the customers were found to be satisfied with all dimensions of perceived price which implied that satisfaction of perceived price fairness led to return intention of customers in the rated restaurants. The study suggested that the restaurant managers should improve on both perceived value and price. They should also ensure that the set prices are not more than the prices of their competitors of the same standard. Investment on staff training was also suggested.
\end{abstract}

Key words: Perceived price fairness, customer satisfaction, loyalty, star rated restaurant

\section{Introduction}

The growth of the restaurant industry in Kenya over the past years can be attributed mainly to a change in the lifestyle of its people. Consumers who most of the time working in the urban areas, have increasingly scarcity of time in cooking at homes. Most of the restaurants are located in the city centers (near work place) thus making it impossible for people to commute to their homes and back to the office during lunch time. This has triggered a tendency to consume food away from home.

Regardless of popularity of eating out [1] and continued growth of the restaurant industry, the failure rate for restaurant is higher than the average rate of small businesses. [2] Identified restaurateurs' inability to satisfy their customers' expectations and needs as one of the main reasons for restaurant failure. Previous research has shown that perceived price fairness correlates with customer satisfaction [3] which is closely linked with customer loyalty
[4]. The purpose of this study is therefore to assess how perceived price fairness influence customer satisfaction and loyalty of customers visiting Kenyan star-rated restaurant.

\section{Main Objective}

To examine the relationship between perceived price fairness with customers' satisfaction and loyalty based on price perception at star-rated restaurants in Nairobi and Coastal region of Kenya.

\section{Research Hypotheses}

H0 $0_{1}$ There would be no relationship between customers' perceived price fairness and satisfaction at star rated restaurants in Nairobi and coastal region.

$\mathbf{H O}_{2}$ There would be no relationship between customers' perceived price fairness and loyalty at star rated restaurants in Nairobi and coastal region. 


\section{Literature Review}

\section{Perceived Price Fairness}

Price is the amount of money exchanged for a product or service or the sum of values that customers exchange for the benefit of acquiring the product or service [5]. The perceived price is an important characteristic that influences purchase decision as well as reasons for patronizing a restaurant [6]. Perceived price fairness can be defined as consumers' assessment of whether a seller' price can reasonably be justified [7]. [8] argued that there are three basic references of prices for consumers in assessing the price fairness. These are; 1$)$ The price in the past, 2) the price applied to competitors and 3) the price charged by the company (restaurant). Perceived price fairness has a positive influence on the customer's intent to purchase [9], a positive influence on customer satisfaction [4], a positive influence on customer loyalty [10] and a positive influence on the buyer's attitude towards the seller [11]. Perceived price unfairness may lead to negative consequences for the restaurateur including customers switching to competing restaurant and spreading negative information. In regard to perceived price and value, [12] posited that food service operator needs to emphasize on good value for the price, appropriate portion size of food and beverage for the price, and overall value of the dining experience to their customers. Appropriate portion size of food, appropriate amount of beverage, good value for the price, price compared to prices of competitors and overall value of the meal experience was therefore used in measuring price perception in this study

\section{Customer Satisfaction and Perceived Price Fairness}

Customer satisfaction can be defined as a customer's perception of the performance of a product or service, in relation to his or her expectations [13]. Perceived price fairness is considered as an important factor for customer satisfaction and revisit intention [14], because customers evaluate the value of service on the basis of price they pay. [15] also reported that price fairness is an important predictor of relationship quality, trust and satisfaction and if customers believe that prices of a restaurant are reasonably high and there are no justifications for such prices, the chances of them visiting lessen. Support came from [4] who asserted that perception of price unfairness lead to dissatisfaction and that purchase intention is influenced by satisfaction.

\section{Customer Loyalty and Perceived Price Fairness}

Customer loyalty is associated with the repetitive purchase behaviors or recommendation to others. According to [16] customer loyalty is when the customer has a desire to buy a product or service from a firm (restaurant) re-purchase, recommend to others and refuse services of a competitor. [7] argue that customer loyalty will serve as a buffer to decrease the negative effect of a comparatively disadvantaged price on price unfairness perception. The relationship between the customer and the restaurant may sustain a certain level of challenge that comes from a relatively small price discrepancy to customers' disadvantage (for example paying a slightly higher price than other customers) [17]. [18] found out that when the price increase was minor, loyal customers view the price increase as more fair than non- loyal customers, on the other hand when loyal customers discover they paid a higher price for the same product service, than comparative others, they may see a disadvantaged price as unfair and feel that the seller has betrayed their relationship [7].

\section{Methodology}

A cross sectional survey study was adopted. This type of study was preferred as it gathers a large scale of data at one point in time and explains phenomenon representing wide populations then simply reports what has been found in a variety of ways [19].The study was conducted in Nairobi (capital city) and coastal region of Kenya. These areas were selected because they have all the star rated restaurants in the country [20]. The two regions also receive the largest number of both domestic and international tourists [21].The target population was all customers, visiting the rated restaurants in Nairobi and Coastal region. The respondents targeted were people who were over 18 years of age and understood and spoke English. The study used simple random sampling technique because simple random sampling involves selecting reasonable numbers of subjects that can represent the target population [22]. The study sampled all star rated restaurants (thirty one), seven in Coastal region and twenty four (24) in Nairobi [20]. A census survey was employed so as to eliminate any sampling error and provide data on all individuals in the population thus ensuring that the study achieves a desirable level of precision [23].The sample size of the customers was calculated 
according to [24] formula which is used in social sciences studies in determining the sample size [22].

$n=\frac{Z^{2} p q}{d^{2}}$

Where $\mathrm{n}=$ the desired sample size (if the target population is greater than

10,000)

$\mathrm{z}=$ the standard normal deviate at required confidence level.

$\mathrm{p}=$ the proportion in the target population estimated to have characteristic being measured. $\quad q=1-p$ and $\mathrm{d}=$ the level of statistical significance

$50 \%$ was used as the estimate of the proportion in the target population, as recommended by [24]. The proportion of the target population was therefore 0.50 ; the $\mathrm{z}$ statistics was 1.96 .

The desired accuracy was 0.05 level, the sample size was as follows:

$\mathrm{n}=\frac{(1.96)^{2}(.50)(.50)}{(.05)^{2}}=384$

The study employed self administered closed ended questionnaire. The first section had five questions which sought to find out the level of satisfaction in relation to perceived price fairness. The second section had three questions which sought to find out the level of agreement in relation to loyalty. The questionnaire was developed from DINESERV scale [25], and related studies of [12]. To be able to measure the level of satisfaction with perceived price, a five point Likert type scale [26] was used. The scale ranged from very dissatisfied-1, dissatisfied-2, unsure-3, satisfied-4 to very satisfied5. Similarly a five point Likert type scale ranging from strongly disagree-1, disagree-2, unsure-3, agree- 4 and strongly disagree- 5 was incorporated in the questionnaire that measured loyalty of the customers.

One restaurant from Nairobi was random sampled for a pre -test. According to [22], a pretest sample should be between $1 \%$ and $10 \%$ depending on the sample size. One out of thirty one restaurants translated to $3 \%$ of the sample size.

\section{Validity and Reliability}

The questionnaire was scrutinized by a group of experts (in the related study) who determined the accuracy of the set items in relation to the concept under study. Internal consistency reliability test was used in testing the reliability of the questionnaire.
Kaiser Meyer Olkin (KMO) measure of sampling adequacy and Bartlett test of sphericity was used to the appropriateness of applying factor analysis [27]. Items of factors were retained if the factor loading was greater than or equal $0.5 .0 .5=\langle\mathrm{KMO}<=1$ [28].

After performing Keiser- Meyer- Olkin and Barlett's test, factor analytic technique was applied with the aim of 1) reducing the number of variables from large to small, 2) detecting structure in the relationships between variables, and 3) providing construct validity evidence. Any variable with factor loading less than 0.3 was disregarded [29]. Cronbach's alpha was then used to test the reliability of each variable retained in each factor.

\section{Data Collection Process}

The process of data collection involved the principle researcher together with two research assistants. The research assistants were trained on data collection before the actual data collection. The customers were assisted in filling the questionnaires so as to address any queries or uncertainties and also minimize errors, inconsistencies and inaccuracies. In cases where the respondents sought to fill the tool without assistance, they were left with the questionnaire to fill then give to the greeter or waiter after filling. The data was collected during lunch and dinner as most customers visit restaurants during this time. A token of a branded biro pen was given to the respondents to encourage them participate in the study.

\section{Data Analysis}

The questionnaires which had been completed successfully were analyzed. SPSS version 18 was used to analyze the data. Analysis of Variance (ANOVA) test and linear regression were used in analyzing the data

\section{Results and Discussions}

Response Rate: The questionnaires distributed to the 30 existing star rated restaurants were 384. However, 345 questionnaires were returned dully filled indicating a response rate of $89.8 \%$ which is above $60 \%$ used as a threshold in social sciences [30].

\section{Customer Satisfaction with Perceived Price}

Customers' level of satisfaction was measured using perceived price dimensions as indicated in Table 1.

\section{Table 1 Customer Satisfaction with Perceived Price}

\begin{tabular}{|l|l|l|l|l|l|l|}
\hline Price & Very & Dissa & Unsure & Satis & Very & Subtotal \\
\hline
\end{tabular}




\begin{tabular}{|l|l|l|l|l|l|l|l|l|}
\hline Dimensions & $\begin{array}{l}\text { Diss } \\
\text { N\% }\end{array}$ & N\% & N\% & N\% & \multicolumn{2}{|l|}{$\begin{array}{l}\text { Satis } \\
\text { N\% }\end{array}$} & \multicolumn{2}{|l|}{$\begin{array}{l}\text { mean } \\
\text { median } \\
\text { mode }\end{array}$} \\
\hline $\begin{array}{l}\text { Appropriate } \\
\text { Portion size } \\
\text { For the price }\end{array}$ & 17.7 & 26.6 & 2.0 & 44.3 & 11.3 & 3 & 4 & 4 \\
\hline $\begin{array}{l}\text { Good value } \\
\text { for price in } \\
\text { relation to } \\
\text { service }\end{array}$ & 6.7 & 36.8 & 3.2 & 43.2 & 10.1 & 3 & 4 & 4 \\
\hline $\begin{array}{l}\text { Appropriate } \\
\text { Amount of } \\
\text { Beverage for } \\
\text { the price. }\end{array}$ & 6.7 & 39.4 & 3.2 & 43.5 & 7.2 & 3 & 4 & 4 \\
\hline $\begin{array}{l}\text { Comparison } \\
\text { of Price with } \\
\text { other } \\
\text { restaurants }\end{array}$ & 28.1 & 27.5 & 5.2 & 29.6 & 9.6 & 3 & 2 & 4 \\
\hline $\begin{array}{l}\text { Overall } \\
\text { value of the } \\
\text { dining } \\
\text { experience } \\
\text { and price }\end{array}$ & 6.4 & 37.4 & 4.6 & 42.3 & 9.3 & 3 & 4 & 4 \\
\hline
\end{tabular}

i. Appropriate Portion Size of Food and Appropriate amount of Beverage for the Price: Table 1 indicates that majority of the respondents $(44.3 \%, 43.5 \%)$ were satisfied with the portion size of food and amount of beverage for the price, $24.6 \%, 39.4 \%$ were dissatisfied, $17.7 \%, 7.2 \%$ very dissatisfied $11.3 \%, 6.7 \%$ very satisfied and $2 \%$, $3.2 \%$ were unsure respectively. The mode of 4 in both cases indicated that most respondents were satisfied with appropriate portion size of food and amount of beverage for the price. This implied that most restaurants gave their customers appropriate portion size of food and appropriate amount of beverage for the price. A study by [31] on 'consumers' attitudes towards point of purchase interventions aimed at portion size' showed that large portions sizes offered more value for money to customers compared to small portion sizes. In the same vein of thought, [32] argued that dissatisfaction with prices of food and beverages may not necessarily mean that the prices offered by an operation is exorbitant, but it may be due to other factors, for instance if the portions of food are not the same for everybody.

\section{ii. Good Value for the Price in Relation to Service:}

Table 1 indicates that most respondents (43.2\%) were satisfied with good value for the price in relation to service $36.8 \%$ were dissatisfied, $10.1 \%$ were very satisfied, $6.7 \%$ very dissatisfied and lastly $3.2 \%$ were unsure. The mode of 4 indicated that most respondents were satisfied with good value for the price in relation to service. This implies that most restaurants offered good value for the price. A study by [33] indicates that the value for money is impacted by quality of food available and diversity of food and beverage. 'When customers encounter a very satisfying restaurant experience, they are likely to believe they have received extremely good value and consequently are likely to return to the same restaurant' [33].

\section{iii. Prices Compared to the Prices of other} Restaurants of the Same Standard: Table 1 shows that majority $(29.6 \%)$ were satisfied with the prices of the restaurants compared with the prices of other restaurants of the same standard, however $28.1 \%$ were very dissatisfied, followed closely by $27.5 \%$ who were dissatisfied, then $9.6 \%$ who were very satisfied and finally $5.2 \%$ who were unsure. The mode of 4 indicated that most respondents were satisfied with the prices compared with the prices of other restaurant of the same standard. However the sum of the percentage of the dissatisfied (27.5\%) and very dissatisfied respondents $(28.1 \%)$ reveals that majority (55.6\%) were dissatisfied and very dissatisfied with the prices compared to the prices of the other restaurants of the same standard. This implies that the respondents had knowledge of the prices of other restaurants in relation to the quality. It also means that the prices could have been higher than the prices of other restaurant of the same standard, leading to dissatisfaction.

According to [36], customers value goods and services of the quality they expect that are sold at the prices that they are willing to pay. How much a customer is willing to pay depends on what they need, what they expect and their evaluation of the quality of service [37]. This means that the customers can easily switch to other restaurants if their needs are not met and the prices are unfavorable.

iv. Overall Value of Dining Experience and Price. Table 1 depicts the overall value of dining experience which was rated as follows; $42.3 \%$ were satisfied, followed by $37.4 \%$ who were dissatisfied, then $9.3 \%$ who were very satisfied, $6.4 \%$ who were very dissatisfied and finally $4.6 \%$ who were unsure. The mode of 4 in all aspects of price indicated that most respondents were satisfied with price. Customer satisfaction in this last stage of the dining experience could also have been as a result of waiters reviewing the bills accurately, handling billing errors competently and giving correct change after billing. In previous research [38] price was one aspect that was unsatisfactory to the customers. When prices are not in accordance with the 
customers' expectations, customer satisfaction declines [1].

\section{Hypothesis Testing of Perceived Price Fairness and Customer Satisfaction}

H0, There would be no significant relationship between customers' perceived price fairness and satisfaction at rated restaurants in Nairobi and Coastal region of Kenya.

Table 2 Regression Analysis for Customer Satisfaction on perceived price fairness

\begin{tabular}{|l|l|l|l|l|l|}
\hline Equation & Variables & $\beta$ & $\begin{array}{l}\text { t- } \\
\text { value }\end{array}$ & $\begin{array}{l}\text { P- } \\
\text { value }\end{array}$ & $\mathbf{R}^{\mathbf{2}}$ \\
\hline $\mathrm{CS}=\mathrm{a}+\beta \mathrm{PP}$ & Perceived & 0.527 & 2.702 & 0.007 & 0.637 \\
$\mathrm{~F}$ & $\begin{array}{l}\text { price } \\
\text { fairness } \rightarrow\end{array}$ & & 24.510 & 0.000 & \\
& $\begin{array}{l}\text { Customer } \\
\text { satisfaction }\end{array}$ & 0.544 & & & \\
& & & & \\
\hline
\end{tabular}

$\mathrm{a}=$ Intercept term, $\beta=$ Regression coefficient, $\mathrm{CS}=$ Customer satisfaction, $\mathrm{PPF}=$ Perceived Price Fairness

Table 2 depicts that perceived price was significant at $\mathrm{R}^{2}$ of $0.637(\mathrm{p}<0.05)$. Hence perceived price fairness has significant relationship with customer satisfaction. Customer satisfaction has a positive influence on loyalty [39]. A study of [40] surprisingly did not show any relationship between customer satisfaction and frequency of patronage. Satisfaction has however been found to be a strong predictor of return intention which culminates loyalty among customers [41]. The null hypothesis $\left(\mathrm{H} \mathrm{O}_{1}\right)$ was therefore rejected.

\section{Hypothesis Testing of Perceived Price and Return Intention}

$\mathbf{H O}_{2}$ There would be no significant relationship between customers' perceived price fairness and loyalty at rated restaurants in Nairobi and Coastal region of Kenya

\section{Regression Analysis \\ Linear Regression Test for Perceived Price \\ Fairness and loyalty}

Linear regression test sought to identify linear relationship between perceived price and return intention. This is illustrated in Figure 1

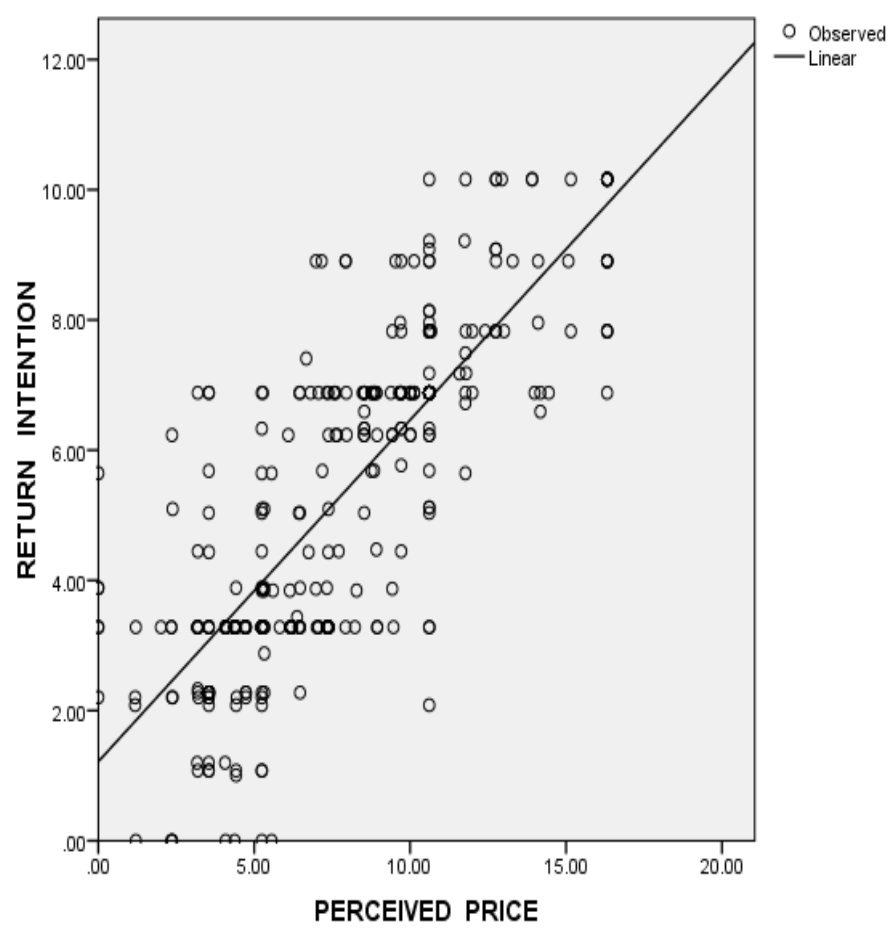

Figure: 1 Linear Relationship of Perceived Price and Return Intention.

The scatter plot graph (Figure 1) indicates that there is a positive relationship between perceived price and return intention. This permits the conducting of regression analysis. Figure 1 also shows that as perceived price increases, return intention also increases which leads to loyalty.

Table 3 Coefficient of Determination for Perceived Price Fairness and Loyalty

\begin{tabular}{|l|l|l|l|l|}
\hline \multicolumn{5}{|c|}{ Model Summary } \\
\hline Model & $\mathrm{R}$ & R Square & $\begin{array}{l}\text { Adjusted } \\
\text { R } \\
\text { Square }\end{array}$ & $\begin{array}{l}\text { Std. } \\
\text { Error of } \\
\text { the } \\
\text { Estimate }\end{array}$ \\
\hline 1 & $.794^{\mathrm{a}}$ & .630 & .629 & 1.50716 \\
\hline
\end{tabular}

a. Dependent Variable: LOYALTY

Predictors (Constant): PERCEIVED PRICE FAIRNESS

The results in Table: 3 show that perceived price fairness accounts for $63 \%$ (R square of 0.63 ) of the variations in loyalty. The rest $37 \%$ can be explained by other factors. As $\mathrm{R}^{2}$ increases, the standard error of the estimate decreases indicating better fit with less estimation.

\section{ANOVA Test for Perceived Price Fairness and Loyalty}

An ANOVA test was done to identify any statistical significance between perceived price fairness and loyalty (Table 4). 
Table: 4 ANOVA Test for Perceived Price Fairness and Loyalty

\begin{tabular}{|l|l|l|l|l|l|l|}
\hline \multicolumn{7}{|c|}{ ANOVA $^{2}$} \\
\hline \multicolumn{2}{|l|}{ Model } & $\begin{array}{l}\text { Sum of } \\
\text { Squares }\end{array}$ & df & $\begin{array}{l}\text { Mean } \\
\text { Square }\end{array}$ & F & Sig. \\
\hline 1 & Regression & 1326.847 & 1 & $\begin{array}{l}1326.84 \\
7\end{array}$ & $\begin{array}{l}584.12 \\
2\end{array}$ & $.000^{\mathrm{b}}$ \\
\hline & Residual & 779.132 & 343 & 2.272 & & \\
\hline & Total & $\begin{array}{l}2105.97 \\
9\end{array}$ & 344 & & & \\
\hline
\end{tabular}

a. Dependent Variable: LOYALTY

Predictors :PERCEIVED PRICE FAIRNESS

The results of ANOVA test (Table 4) reveal that at a P-value of $0.000(p<0.05)$, there is a statistical significance between perceived price fairness and loyalty at 0.05 confidence level. This means that the perceived price fairness significantly predicts loyalty. The regression model is therefore a good fit for the data.

\section{Regression Analysis for Perceived Price Fairness and Loyalty}

A regression equation known as a regression model was formulated to determine the relationship between perceived price fairness and loyalty. Table 5 depicts the regression analysis for perceived price and loyalty.

Table: 5 Regression Analyses

\begin{tabular}{|c|c|c|c|c|c|c|}
\hline \multicolumn{7}{|c|}{ Coefficients $^{\mathrm{a}}$} \\
\hline & & \multicolumn{2}{|c|}{$\begin{array}{l}\text { Unstandardized } \\
\text { Coefficients } \\
\end{array}$} & \multirow{2}{*}{$\frac{\frac{\text { Std. }}{\text { Coeffi. }}}{\text { Beta }}$} & \multirow[t]{2}{*}{$\mathrm{t}$} & \multirow[t]{2}{*}{ Sig } \\
\hline & & $\bar{\beta}$ & Std.Error & & & \\
\hline \multirow[t]{2}{*}{1} & (Constant) & 1.216 & .191 & & 6.370 & .000 \\
\hline & $\begin{array}{l}\text { Perceived } \\
\text { Price } \\
\text { Fairness }\end{array}$ & .525 & .022 & .794 & 24.169 & .000 \\
\hline
\end{tabular}

a. Dependent Variable: LOYALTY

The results in Table 5 shows that $\mathrm{Y}=1.216+$ $0.525 \mathrm{X}$.A unit change in perceived price fairness changes loyalty at the rate of 0.525 . A positive coefficient on $\mathrm{X}\left(\beta_{1}=0.525\right)$ means that perceived price fairness has a positive effect on loyalty. A pvalue of $0.000 \quad(\mathrm{p}<0.05)$ indicates that there is significant relationship between perceived price fairness and loyalty. The null hypothesis $\left(\mathrm{HO}_{2}\right)$ was therefore rejected.

\section{Conclusions}

The results in Table 1 indicate that majority of the customers were satisfied with all dimensions of perceived price. Regression analysis done to test both hypotheses revealed a significant association between perceived price fairness with satisfaction and loyalty which led to the rejection of both null hypotheses. The results clearly shows that customers' satisfaction and loyalty is based on fairness of price perception. If customers perceive that the prices charged at the restaurants are fair, then they will fill satisfied and will also have intention of revisiting the restaurant again. These findings are congruent with the findings of [42] who found that perceived price fairness was significant to customers when making purchase and loyalty at the restaurants. Other support comes from previous findings of; [42] and [43] who also revealed that perceived price fairness had a significant positive effect on customer satisfaction and return intention. If customers on the other hand perceive that the prices charged are unfair, this would lead to higher degree of dissatisfaction, lower level of repurchase intention negative word of mouth and increased customer complaints [44].

The study suggests that the restaurant managers should improve and maintain both perceived value and perceived price. They should analyze how customers form their price perception. The managers must know the internal reference price of their customers, which can be measured through the mean price that the customers expect to pay for the service offered by their restaurants. If these prices correspond to the sale price, this objective is perceived correctly. The customers will then perceive that the prices are fair. The study also suggests that the managers should ensure that the food portions are all the same and are worth of the prices sold. They should ensure that the prices are in harmony with the prices of competitors to prevent the customers switching from their restaurant and at the same time ensuring satisfaction. Investment on waiters training on customer handling would also be important.

\section{Acknowledgements}

The author would like to thank the National Commission for Science Technology and Innovation (NACOSTI) and managers of various star rated restaurants for allowing data collection in various restaurants.

\section{References}

[1] S. Andaleeb \& C. Conway. Customer Satisfaction in the Restaurant Industry: An examination of the transaction- specific model. Journal of Services Marketing, 20 (1):3-11, 2007. 
[2] .G. Chi, and D. Gursoy, Employee satisfaction, customer satisfaction and financial performance. An empirical analysis. International Journal of Hospitality Management, 28 (2): 245- 254, 2009.

[3] L. Ordenez, C. Connolly and R. Coughlan. Multiple reference points in satisfaction and fairness assessment. Journal of Behavioural Decision Making, 13 (3) 329-344, 2000.

[4] R.L. Oliver, and J.E. Swan, Consumer perceptions of interpersonal equity and satisfaction in transactions: A field survey approach. Journal of Marketing Decisions, 53 (4), 21-35, 1989.

[5] P. Kotler \& G. Armstrong, Principals of Marketing $14^{\text {th }}$ Edition Pearson Education. 2010.

[6] L. Gikonyo, A. Bernt \& J. Wadawi, Critical success factors for franchised restaurants entering the Kenyan market: Customers perspective. International Journal of Management and Sustainability, 3(7):433447, 2014.

[7] L. Xia, K.B.Monroe, \& J.L.Cox, The price is unfair !a conceptual Frame work of price fairness perception.Journal of Marketing, 68 (10), 1-15, 2004.

[8] D.Martin-Ruiz and F.J. Rondan- Cataluna, The nature and Consequences of Price unfairness in Service: a comparison to tangible goods. International Journal of Service Industry Management, 19 (3):325-352, (2008)

[9] I. Daskalopoulou, Fairness perceptions and observed customer behaviour: Results of a partial observability model, Journal of SocioEconomics, 37,(3), 31-44, 2008.

[10] L.T. Bei and Y-C. Chiao,An Integrated Model for the Effects of Perceived Product, Perceived Service Quality and Perceived Price fairness on Consumer Satisfaction and Loyalty. Journal of Consumer Satisfaction, Dissatisfaction and Complaining Behaviour, 14: 125, 2001

[11] S. Maxwell, Rule based Price fairness and its effect on willingness to purchase. Journal of Economic Psychology, 23: 191-212, 2002.

[12] L. Xi, \& Z. Shuai, Investigating of customer satisfaction in student food service. An example of student Cafeteriain NHH. International Journal of Quality and Service Sciences, 1(1):113- 124, 2009.

[13] L.G. Schiffman \& L.L. Kanuk, Consumer Behavior, 10th Edition, Boston:Pearson Prentice Hall, 2010.
[14] S. Samaedi, I.G. Bakti, \& N. Metasari, The effect of students perceived service quality and perceived price as student satisfaction. Management Science and Engineering. 5 (1): 88-97, 2011.

[15] W.G. Kim, Y.K. Lee, \& Y.J. Yoo, Predictors of relationship quality and relationship outcomes in luxury restaurant. Journal of Hospitality and Tourism Research, 30 (2):143169, 2006.

[16] M.H.Huang, Re- examining the effect of service recovery. The moderating role of brand equity. Journal of Service Marketing 25 (7):509-516, 2011.

[17] R.J. Lewicki, \& B.B. Bunker, Trust in relationships: A model of development and decline. In B. B. Bunker and J. Z. Rubin (Eds), Conflict, Cooperation, and Justice, (pp. 133-173). San Francisco, CA: Jossey-Bass, 1995.

[18] W.C.Martin ,N.Ponder \& J.E. Lueg, Price Fairness perceptions and customer loyalty in a retail context. Journal of Business Research, 62, 588-593, 2009.

[19] L.M. Cohen, Research methods in Education. London: Rouledge Falmer, 2011.

[20] Kenya Gazette Notice No. 3976. The Hotel and Restaurant (Classification of Hotels and Restaurants) regulation, 1988 Classification. Vol CV-No.62, Nairobi. 13 ${ }^{\text {th }}$ June 2003.

[21] Kenya National Bureau of Statistics Visitors statistics. Tourism Bulletin;. No. 9, 2012.

[22] O. Mugenda, \& A. Mugenda, A Research Methods, Quantitative and Qualitative Approaches. Revised Edition. African Centre of Technology Studies Press, 2003.

[23] G.G.Israel, Determining Sample Size Program Evaluation and Organizational Development, IFAS, University of Florida. PEOD- 6, 1992.

[24] A. Fisher, J. Laing, E. Stoekel, \& J. Townsend, Handbook for Family Planning Operations Research Design ( $2^{\text {nd }}$ Edition). Population council. New York, 1998.

[25] P. Stevens, B. Knutson, \& M. Patton, DINESERV; A Tool for measuring Service Quality in Restaurants. Cornell Hotel and Restaurant Administration Quarterly, 36 (2): 56- 60, 1995.

[26] N. Geoff, "Likert" Scale Levels of measurement and the laws of statistics. Advances in Health Science Education. 15 (5): 625-632, 2010. 
[27] J.J. Pallant, SPSS Survival Manual: A Step by Step guide to data analysis using SPSS for windows (Version 12), 2005.

[28] H. Trong, \& M. Ngo, Analysis of research data with SPSS. vol 2, Hong Duc Publisher Ho Chi Minh, Vietnam, 2008.

[29] C. De Stefano, M. Zhu, \& D. Miudrila, Practical assessment research and evaluation. Computing Factor Scores, 14 (12): 1- 11, 2009.

[30] T.P. Johnson, \& J.S. Wislar, Response Rate and Non Response Errors in Surveys. JAMN, 307:1805- 1806, 2012.

[31] W.M. Vemeer, I.H. Steenhuis, J.C. Seidell, Portion size: a qualitative study of consumers' attitudes toward point of purchase interventions aimed at portion size. Health Education Research, 25 (1): 109- 120, 2010.

[32] M.C. Spears, \& M.B. Gregoire, Food service organizations $\left(5^{\text {th }}\right.$ Ed), New Jersey: Pearson Education, 2004.

[33] T. Smith, \& A.J. Spencer, Predictors of value for money in Jamaican All inclusive hotels. International Journal of Humanities \& Social Sciences, 1(4) 93- 102, 2011.

[34] Kenya Law Reports, The Hotel and Restaurant Act, Chapter 494, revised Edition, part VI, Catering Levy, 2009.

[35] Kenya Revenue Authority, Domestic Taxes Department, the Value Added Tax Act, Chapter 476 and subsidiary legislation. Revised Edition. 2004.

[36] A.Brink, \& A. Berndt, Relationship Marketing and Customer Relationship Management and Customer Service. Landowne: Juta, 2008.

[37] J. Li, Factors affecting customer satisfaction and customer loyalty towards Belle Footware company in Lanzhou City, Gansu, Province of the people republic of China. Journal of Business and Management, 14 (2): 41- 48, 2013.

[38] A. Yuksel, \& F. Yuksel, Measurement of tourist satisfaction with restaurant services. A segment based approach. Journal of Vacation Marketing, 1 (9): 52-68, 2002.

[39] S.N. Sharif, M.B. Omar, S.N. Sulong, H.A. Majid, H.B. Ibrahim, Z.B. Jaafar \& M.S. Ideris, The influence of service quality and food quality towards customer fulfilment and revisit intention. Canadian Social Science, 11(8):110- 116, 2015.

[40] K.N. Kanta, \& P. Slivalli,. A study on service quality in India Restaurants with decision- and experientialoriented
International Journal of Research and Development, 3(1): 16-24, 2014.

[41] R.S. Harrington, M.C.Ottenbacher, \& K.W. Kendell, Fine Dining Restaurant Selection: Direct and Moderating Effects of Customer's Attributes. Journal of Food Service Business Research, 14: 272- 289, 2013.

[42] J. Hanaysha, Restaurant Location and Price Fairness as Key Determinants of Brand Equity: A Study on Fast Food Restaurant Industry. Business and Economics Research, 6(1): 310- 323, 2016.

[43] L.W. Wang, T.T. Tran, \& N.T. Nguyen, Analysing Factors to Improve Service Quality of Local Specialities Restaurants: A Comparison with Fast Food Restaurants in Southern Vietnam. Asian Economic and Financial Review, 4(11): 1592- 1606, 2015.

[44] S. Rothenberger, Fairness Through Transparency: The Influence of Price Transparency on Consumer Perception of Price Fairness. Working Papers CEB, 15, 2015.

\section{Author Profile}

Margaret Githiri received the MSC in Tourism and Hospitality and Phd degree in Hospitality Management from Kenyatta University, Kenya in 2008 and 2017 respectively. She is a lecturer at the Faculty of Environmental and Resource Development of Egerton University, Kenya. She is currently a programme co-ordinator of Bachelor of Science in Ecotourism and Hospitality Management. Her research interest is in Hospitality and Tourism trends. 